\title{
Efficacy and Tolerability of Candesartan Cilexetil and Amlodipine in Patients with Poorly Controlled Essential Hypertension
}

\author{
-Efficacy of Candesartan and Amlodipine
}

\section{Kazuaki Nishio, Takeshi Kondo, Youichi Kobayashi}

The Third Department of Internal Medicine, School of Medicine, Showa University, Tokyo, Japan.

Email: kazukun@jg7.so-net.ne.jp

Received August $13^{\text {th }}, 2010$; revised January $7^{\text {th }}, 2011$; accepted January $15^{\text {th }}, 2011$.

\begin{abstract}
Current treatment guidelines for hypertension in both Europe and the USA stress the importance of aggressive blood pressure control. When monotherapy is not enough to reach treatment targets, there is a need for combination regimens that have both high efficacy and good tolerability. The aim of this study is to evaluate the efficacy and tolerability of the combination therapy candesartan and amlodipine in patients with hypertension not satisfactorily controlled by monotherapy. Patients with uncomplicated essential hypertension not satisfactorily controlled by monotherapy, which is candesartan $8 \mathrm{mg}$ or amlodipine $5 \mathrm{mg}$, were eligible. Candesartan $8 \mathrm{mg}$ and amlodipine $5 \mathrm{mg}$ were given for 12 weeks. 13 patients who received candesartan $8 \mathrm{mg}$ previoursly were assigned to the candesartan group and 8 patients who received amlodipine $5 \mathrm{mg}$ previoursly were assigned to the amlodipine group. Sitting systolic blood pressure (SBP) at baseline was $151.9 \pm 11.6 \mathrm{mmHg}$ in the candesartan group, and $154.6 \pm 7.6 \mathrm{mmHg}$ in the amlodipine group. Sitting diastolic blood pressure $(D B P)$ was $93.2 \pm 13.1$ in the candesartan group, and $80.4 \pm 14.7$ in the amlodipine group. $D B P$ in the amlodipine group was lower than that in the cadesartan group $(P=0.036)$. After the combination therapy, $S B P$ was significantly reduced in the two groups. DBP showed significant reduction in the amlodipine group. The rate of achieving blood pressure goals was $4 \%$ at baseline and significantly increased to $58 \%$ after the combination therapy. These results showed that candesartan $8 \mathrm{mg} /$ amlodipine $5 \mathrm{mg}$ are effective lowering blood pressure after 12 weeks in patients not adequately controlled by monotherapy.
\end{abstract}

Keywords: Amlodipine, Candesartan, Combined Therapy, Hypertension

\section{Introduction}

Angiotensin II type I (AT1) receptor antagonists are a widely used class of antihypertensive agents. Candesartan is a selective long-acting AT1 receptor antagonist. The drug is administered orally as candesartan cilexetil, an ester prodrug that is rapidly and completely converted to the active moiety during gastrointestinal absorption. [1] Previous studies have shown candesartan cilexetil to be efficacious and well tolerated in patients with mild-tomoderate essential hypertension [2,3]. There is evidence that it may confer target organ protection beyond that attributable to the reduction of blood pressure [4-6]. Recent studies have shown that candesartan also has favorable effects on mortality and cardiovascular morbidity in patients with chronic congestive heart failure [7-9]. How- studies suggest that antihypertensive mono- therapy generally controls blood pressure in only $50 \%$ to $60 \%$ of patients [10]. Current treatment guidelines for hypertension in both Europe and the USA stress the importance of aggressive blood pressure control $[11,12]$. When monotherapy is not enough to reach treatment targets, there is a need for combination regimens that have both high efficacy and good tolerability. Indeed, there is evidence that some $40 \%-60 \%$ of patients with hyper- tension will need such combination treatment, largely depending on the amount of BP reduction needed to reach target BP [11-13].

The aim of this study is to evaluate the efficacy and tolerability of the combination therapy candesartan and amlodipine which is the commonly-used calcium channel blocker, in patients with hypertension not satisfactorily 
controlled by monotherapy.

\section{Methods}

Patients with uncomplicated essential hypertension not satisfactorily controlled by monotherapy, which is candesartan $8 \mathrm{mg}$ or amlodipine $5 \mathrm{mg}$, were eligible. Candesartan $8 \mathrm{mg}$ and amlodipine $5 \mathrm{mg}$ were given orally once daily in the morning. The subjects were 21 outpatients of our hospital who consented to participation in this study. Informed consent was obtained from all patients recruited into the study. The inclusion criteria were a sitting systolic blood pressure (SBP) greater than 130 $\mathrm{mmHg}$ or a sitting diastolic blood pressure (DBP) greater than $80 \mathrm{mmHg}$ with monotherapy. The primary objective was to evaluate the effects of the combination therapy of candesartan $8 \mathrm{mg}$ and amlodipine $5 \mathrm{mg}$ on sitting BP for 12 weeks. 13 patients who received candesartan $8 \mathrm{mg}$ previoursly were assigned to the candesartan group and 8 patients who received amlodipine $5 \mathrm{mg}$ previoursly were assigned to the amlodipine group. Safety variables were adverse events, adverse drug reaction, haematology, blood chemistry, urinary, and physical examination.

\section{Clinical Procedures}

At Visit 1 (week -2), eligible patients were enrolled, and continued with their existing monotherapy up to Visit 2 (week 0). At Visit 2, eligible patients received the other drug which is candesartan $8 \mathrm{mg}$ or amlodipine $5 \mathrm{mg}$, to be continued up to Visit 3 (week 2). At Visit 3, efficacy and safety of treatment were assessed. Blood pressure measurements were made at about the same time in the morning, after sitting for at least ten minutes.

\section{Statistical Analyses}

Blood pressure was evaluated by analysis of covariance with the baseline value as the covariate. Blood pressure and laboratory results were evaluated using paired t-test where appropriate. Differences in the categorical data were analyzed by $\chi^{2}$ analysis, and the Fisher's exact test was used when appropriate. Differences were considered to be statistically significant when the $P$ values was 0.05 .

\section{Results}

\subsection{Clinical Characteristics of the Patients}

Clinical characteristics of patients are shown in Table $\mathbf{1 .}$ Overall, $66.6 \%$ of patients were men, and the mean age was 61.7 years. A total of 13 patients were assigned to the cadesartan group, and 8 patients were assigned to the amlodipine group. There were no significant differences in age and sex ratio in the two groups at baseline.

\subsection{Blood Pressure Monitoring}

SBP and DBP of patients are shown in Figures 1-3.
Table 1. Clinical Characteristics of Patients.

\begin{tabular}{|c|c|c|c|}
\hline & $\begin{array}{l}\text { Amlodipine } \\
\text { group }\end{array}$ & $\begin{array}{l}\text { Candesartan } \\
\text { group }\end{array}$ & $\begin{array}{c}P \\
\text { Values }\end{array}$ \\
\hline & $(N=8)$ & $(N=13)$ & \\
\hline Age (yrs) & $68.0 \pm 10.5$ & $57.9 \pm 17.6$ & 0.227 \\
\hline Male sex $(\%)$ & $6(75.0 \%)$ & $8(61.5 \%)$ & 0.856 \\
\hline $\begin{array}{l}\text { Systolic blood pressure } \\
(\mathrm{mmHg})\end{array}$ & $154.6 \pm 7.6$ & $151.9 \pm 11.6$ & 0.213 \\
\hline $\begin{array}{l}\text { Distolic blood pressure } \\
(\mathrm{mmHg})\end{array}$ & $80.4 \pm 14.7$ & $93.2 \pm 13.2$ & 0.036 \\
\hline GOT (IU/l) & $23.3 \pm 4.7$ & $32.9 \pm 24.3$ & 0.231 \\
\hline Follow up & $21.5 \pm 3.4$ & $24.4 \pm 10.8$ & 0.462 \\
\hline$P$ Values & 0.469 & 0.282 & \\
\hline GPT (IU/l) & $18.8 \pm 4.44$ & $48.0 \pm 55.1$ & 0.212 \\
\hline Follow up & $13.8 \pm 1.7$ & $32.5 \pm 27.3$ & 0.223 \\
\hline$P$ Values & 0.113 & 0.311 & \\
\hline BUN (mmol/l) & $946.7 \pm 261.5$ & $934.6 \pm 286.3$ & 0.804 \\
\hline Follow up & $797.0 \pm 185.6$ & $839.4 \pm 232.2$ & 0.372 \\
\hline$P$ Values & 0.464 & 0.069 & \\
\hline Creatinine $(\mu \mathrm{mol} / \mathrm{l})$ & $69.4 \pm 14.9$ & $70.6 \pm 16.1$ & 0.7 \\
\hline Follow up & $70.1 \pm 10.5$ & $73.5 \pm 8.8$ & 0.523 \\
\hline$P$ Values & 0.539 & 0.272 & \\
\hline $\mathrm{Na}(\mathrm{mmol} / \mathrm{l})$ & $141.5 \pm 1.8$ & $143.4 \pm 1.1$ & 0.225 \\
\hline Follow up & $141.7 \pm 1.5$ & $141.5 \pm 2.4$ & 0.18 \\
\hline$P$ Values & 0.13 & 0.018 & \\
\hline $\mathrm{K}(\mathrm{mmol} / \mathrm{l})$ & $4.3 \pm 0.3$ & $4.1 \pm 0.5$ & 0.389 \\
\hline Follow up & $4.5 \pm 0.3$ & $4.0 \pm 0.3$ & 0.372 \\
\hline$P$ Values & 0.13 & 0.67 & \\
\hline $\mathrm{Cl}(\mathrm{mmol} / \mathrm{l})$ & $102.5 \pm 3.1$ & $105.1 \pm 1.1$ & 0.134 \\
\hline Follow up & $103.0 \pm 1.0$ & $104.5 \pm 1.4$ & 0.035 \\
\hline$P$ Values & 0.89 & 0.18 & \\
\hline
\end{tabular}

Data are presented as the mean value $\pm \mathrm{SD}$ or percentage of patients.

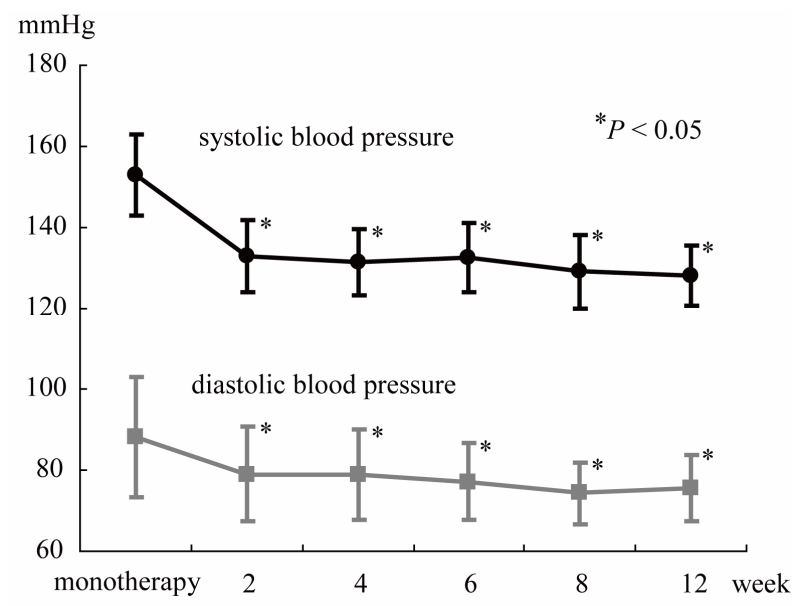

Figure 1. All patients. 


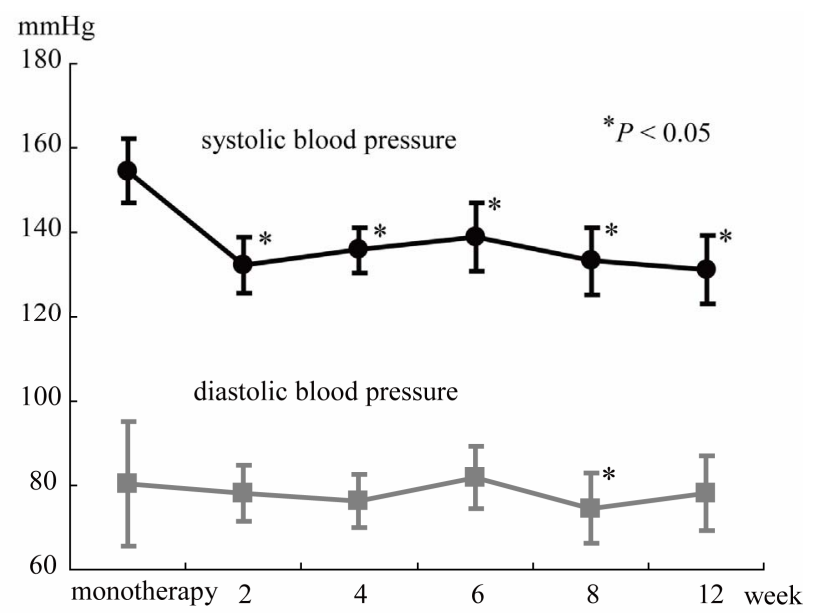

Figure 2. The amlodipine group.

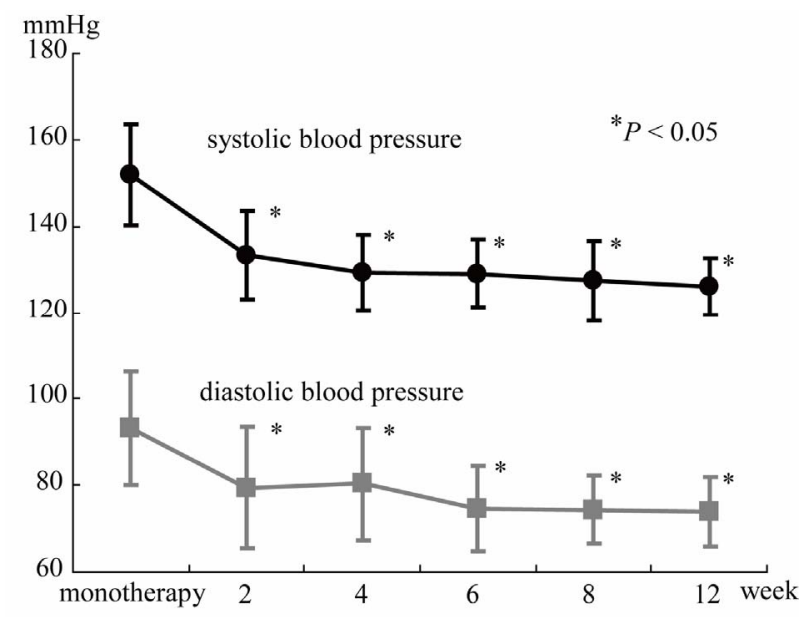

Figure 3. The candesartan group. Effects of the combination therapy with candesartan and amlodipine on blood pressure. $* P<0.05$ vs 0 month.

Values for sitting SBP at baseline was $151.9 \pm 11.6$ in the candesartan group, and $154.6 \pm 7.6$ in the amlodipine group. There was no significant differences between two groups. However, Values for sitting DBP was $93.2 \pm$ 13.1 in the candesartan group, and $80.4 \pm 14.7$ in the amlodipine group. DBP in the amlodipine group was lower than that in the cadesartan group $(P=0.036)$. After the combination therapy, SBP was significantly reduced in the two groups. On the other hand, DBP showed significant reduction in the cadesartan group and no significant reduction in the amlodipine group. There was no significant differeces between two groups after the combination therapy. The rate of achieving blood pressure goals was $4 \%$ at baseline and significantly increased to $58 \%$ after the combination therapy.

\subsection{Laboratory Characteristics of Patients}

Laboratory characteristics of patients are shown in Table
1. There were no significant differences in liver function or renal function in the two groups at baseline or at follow-up. Serum chloride in the amlodipine group was lower than that in the candesartan group $(P=0.035)$ and serum sodium at follow up was lower than that at baseline in the candesartan group $(P=0.018)$.

\subsection{Safety of Treatment}

The combination therapy was well tolerated in all patients, and no patients had side effects and there was no adverse events in the two groups.

\section{Discussion}

The CASTLE study have evaluated the efficacy and tolerability of candesartan cilexetil and amlodipine in an 8 -week in patients with mild hypertension [14]. There were no significant differences between the candesartan cilexetil and amlodipine regimens for reducing BP. However, patients were uptitrated to candesartan cilexetil 32 $\mathrm{mg}$ or amlodipine $10 \mathrm{mg}$ once daily in this study. In the present study, DBP in the amlodipine group was lower than that in the cadesartan group at baseline. After the combination therapy, DBP showed significant reduc- tion in the candesartan group and no significant reduction in the amlodipine group. These results may suggest that amlodipine reduces DBP higher than candesartan cilexetil in patients with hypertension not satisfactorily controlled by monotherapy.

Farsang et al. demonstrated that co-administration of candesartan cilexetil and amlodipine resulted in statistically significant greater blood pressure reductions than the monotherapy in patients with primary hypertension [15]. However, patients were randomized to once-daily treatment with candesartan cilexetil $8 \mathrm{mg}$, amlodipine 5 $\mathrm{mg}$, candesartan cilexetil $8 \mathrm{mg}$ plus amlodipine $5 \mathrm{mg}$ in this study. This study had not demonstrated the course of reduction of blood pressure. The present study demonstrated that the combination therapy rapidly decreased SBP and DBP, and significantly increased the rate of achieving blood pressure goals from $4 \%$ at baseline to $58 \%$ in patients not adequately controlled by monotherapy.

The combination of candesartan cilexetil and amlodipine was very well tolerated in the present patients.

Amlodipine and candesartan cilexetil significantly increase in urine flow, renal sodium, chloride and potassium excretion. [16,17] The present study demonstrate that serum chloride in the amlodipine group was lower than that in the candesartan group and serum sodium at follow up was lower than that at baseline in the candesartan group. However, values of serum sodium and serum chloride were within the normal range. CASE-J Ex is in progress to evaluate the long- 
term effects of candesartan and amlodipine on cardiovascular mortality and morbidity in high-risk hypertensive patients [18].

In summary, our results show that candesartan $8 \mathrm{mg} /$ amlodipine $5 \mathrm{mg}$ are effective lowering blood pressure after 12 weeks in patients not adequately controlled by monotherapy.

\section{REFERENCES}

[1] R. Hübner, A. M. Högemann, M. Sunzel and J. G. Riddell, "Pharmacokinetics of Candesartan after Single and Repeated Doses of Candesartan Cilexetil in Young and Elderly Healthy Volunteers," Journal of Human Hypertension, Suppl. 2, 1997, pp. S19-S25.

[2] P. Sever and H. Holzgreve, "Long-Term Efficacy and Tolerability of Candesartan Cilexetil in Patients with Mild to Moderate Hypertension," Journal of Human Hypertension, Suppl. 2, 1997, pp. S69-S73.

[3] D. Elmfeldt, M. George, R. Hübner and B. Olofsson, "Candesartan Cilexetil, a New Generation Angiotensin II Antagonist, Provides Dose Dependent Antihypertensive Effect," Journal of Human Hypertension, Suppl. 2, 1997, pp. S49-S53.

[4] C. E. Mogensen, S. Neldam, I. Tikkanen, S. Oren, R. Viskoper, R. W. Watts and M. E. Cooper, "Randomised Controlled Trial of Dual Blockade of Renin-Angiotensin System in Patients with Hypertension, Microalbuminuria, and Non-Insulin Dependent Diabetes: The Candesartan and Lisinopril Microalbuminuria (CALM) Study," British Medical Journal, Vol. 321, No. 7274, 2000, pp. 14401444. doi:10.1136/bmj.321.7274.1440

[5] K. Kurokawa, "Effects of Candesartan on the Proteinuria of Chronic Glomerulonephritis," Journal of Human Hypertens, Suppl. 1, 1999, pp. S57-S60.

[6] M. J. Krimholtz, J. Karalliedde, S. Thomas, R. Bilous, and G. Viberti, "Targeting Albumin Excretion Rate in the Treatment of the Hypertensive Diabetic Patient with Renal Disease," Journal of the American Society Nephrology, Vol. 16, No. 3, Suppl. 1, 2005, pp. S42-S47. doi:10.1681/ASN.2004110973

[7] S. D. Solomon, D. Wang, P. Finn, H. Skali, L. Zornoff, J. J. McMurray, K. Swedberg, S. Yusuf, C. B. Granger, E. L. Michelson, S. Pocock and M. A. Pfeffer, "Effect of Candesartan on Cause-Specific Mortality in Heart Failure Patients: The Candesartan in Heart Failure Assessment of Reduction in Mortality and Morbidity (CHARM) Program," Circulation, Vol. 110, No. 2073, 2004, pp. 2180-2183. doi:10.1161/01.CIR.0000144474.65922.AA

[8] J. B. Young, M. E. Dunlap, M. A. Pfeffer, J. L. Probstfield, A. Cohen-Solal, R. Dietz, C. B. Granger, J. Hradec, J. Kuch, R. S. McKelvie, J. J. McMurray, E. L. Michelson, B. Olofsson, J. Ostergren, P. Held, S. D. Solomon, S. Yusuf and K. Swedberg, "Candesartan in Heart Failure Assessment of Reduction in Mortality and Morbidity (CHARM) Investigators and Committees. Mortality and Morbidity Reduction with Candesartan in Patients with Chronic Heart Failure and Left Ventricular
Systolic Dysfunction: Results of the CHARM Low-Left Ventricular Ejection Fraction Trials," Circulation, Vol. 110, October 2004, pp. 2618-2626. doi:10.1161/01.CIR.0000146819.43235.A9

[9] E. O’Meara, S. Solomon, J. McMurray, M. Pfeffer, S. Yusuf, E. Michelson, C. Granger, B. Olofsson, J. B. Young and K. Swedberg, "Effect of Candesartan on New York Heart Association Functional Class. Results of the Candesartan in Heart Failure: Assessment of Reduction in Mortality and Morbidity (CHARM) Programme," European Heart Journal, Vol. 25, No. 21, 2004, pp. 1920-1926. doi:10.1016/j.ehj.2004.07.025

[10] B. J. Materson, D. J. Reda, W. C. Cushman, B. M. Massie, E. D. Freis, M. S. Kochar, R. J. Hamburger, C. Fye, R. Lakshman, J. Gottdiener, E. A. Ramirez and G. Willium, "Single-Drug Therapy for Hypertension in Men. A Comparison of Six Antihypertensive Agents with Placebo. The Department of Veterans Affairs Cooperative Study Group on Antihypertensive Agents," The New England Journal of Medicine, Vol. 328, No. 13, 1993, pp. 914-921. doi:10.1016/j.ehj.2004.07.025

[11] A. V. Chobanian, G. L. Bakris, H. R. Black, W. C. Cushman, L. A. Green , J. L. Izzo Jr, D. W. Jones, B. J. Materson, S. Oparil, J. T. Wright Jr and E. J. Roccella; National Heart, Lung, and Blood Institute Joint National Committee on Prevention, Detection, Evaluation, and Treatment of High Blood Pressure; National High Blood Pressure Education Program Coordinating Committee, "The Seventh Report of the Joint National Committee on Prevention, Detection, Evaluation, and Treatment of High Blood Pressure: The JNC 7 Report," The Journal of the American Medical Association, Vol. 289, No. 19, 2003, pp. 2560-2572. doi:10.1001/jama.289.19.2560

[12] G. Mancia, G. De Backer, A. Dominiczak, R. Cifkova, R. Fagard, G. Germano, G Grassi, A. M. Heagerty, S. E. Kjeldsen, S. Laurent, K. Narkiewicz, L. Ruilope, A. Rynkiewicz, R. E. Schmieder, H. A. Boudier, A. Zanchetti, A. Vahanian, J. Camm, R. De Caterina, V. Dean, K. Dickstein, G. Filippatos, C. Funck-Brentano, I. Hellemans, S. D. Kristensen, K. McGregor, U. Sechtem, S. Silber, M. Tendera, P. Widimsky, J. L. Zamorano, S. Erdine, W. Kiowski, E. Agabiti-Rosei, E. Ambrosioni, L. H. Lindholm, M. Viigimaa, S. Adamopoulos, E. AgabitiRosei, E. Ambrosioni, V. Bertomeu, D. Clement, S Erdine, C. Farsang, D. Gaita, G. Lip, J. M. Mallion, A. J. Manolis, P. M. Nilsson, E. O’Brien, P. Ponikowski, J. Redon, F. Ruschitzka , J. Tamargo, P. van Zwieten, B. Waeber and B. Williams, "Management of Arterial Hypertension of the European Society of Hypertension; European Society of Cardiology, '2007 Guidelines for the Management of Arterial Hypertension: The Task Force for the Management of Arterial Hypertension of the European Society of Hypertension (ESH) and of the European Society of Cardiology (ESC)," Journal of Hypertens, Vol. 25, No. 6, 2007, pp. 1105-1187. doi:10.1097/HJH.0b013e3281fc975a

[13] W. C. Cushman, C. E. Ford, J. A. Cutler, K. L. Margolis, B. R. Davis, R. H. Grimm, H. R. Black, B. P. Hamilton, J. Holland, C. Nwachuku, V. Papademetriou, J. Probstfield, 
J. T. Wright Jr, M. H. Alderman, R. J. Weiss, L. Piller, J. Bettencourt and S. M. Walsh; ALLHAT Collaborative Research Group, "Success and Predictors of Blood Pressure Control in Diverse North American Settings: The Antihypertensive and Lipid-Lowering Treatment to Prevent Heart Attack Trial (ALLHAT)," The Journal of Clinical Hypertens (Greenwich), Vol. 4, No. 6, 2002, pp. 393-404.

[14] R. A. Kloner, M. Weinberger, J. L. Pool, S. G. Chrysant, R. Prasad, S. M. Harris, T. M. Zyczynski, N. K. Leidy and E. L. Michelson; Comparison of Candesartan and Amlodipine for Safety, Tolerability and Efficacy (CASTLE) Study Investigators, "Comparative Effects of Candesartan Cilexetil and Amlodipine in Patients with Mild Systemic Hypertension. Comparison of Candesartan and Amlodipine for Safety, Tolerability and Efficacy (CASTLE) Study Investigators," American Journal of Cardiology, Vol. 87, No. 6, 2001, pp. 727-731. doi:10.1016/S0002-9149(00)01491-0

[15] C. Farsang, K. Kawecka-Jaszcz, J. Langan, F. Maritz and F. Zannad, "Antihypertensive Effects and Tolerability of Candesartan Cilexetil alone and in Combination with
Amlodipine," Clinical Drug Investigation, Vol. 21, No. 1, 2001, pp. 17-23.

[16] J. Greven, "Effect of the Novel T-Selective Calcium Channel Antagonist Mibefradil on Kidney Function in Comparison with Amlodipine," Arzneimittelforschung, Vol. 48, No. 8, 1998, pp. 806-810.

[17] J. L. Andersen, N. C. Sandgaard and P. Bie, "Volume Expansion during Acute Angiotensin II Receptor (AT(1)) Blockade and NOS Inhibition in Conscious Dogs," American Journal of Physiology-Regulatory Integrative and Comparative Physiology, Vol. 282, No. 4, 2002, pp. R1140-R1148.

[18] K. Ueshima, K. Oba, S. Yasuno, A. Fujimoto, T. Sato, K. Fukiyama, J. Azuma, T. Ogihara, T. Saruta and K. Nakao; Candesartan Antihypertensive Survival Evaluation in Japan Trial Group, "Long-Term Effects of Candesartan and Amlodipine on Cardiovascular Mortality and Morbidity in Japanese High-Risk Hypertensive Patients: Rationale, Design, and Characteristics of Candesartan Antihypertensive Survival Evaluation in Japan Extension (CASE-J Ex)," Contemporary Clinicla Trials, Vol. 30, No. 1, 2009, pp. 97-101. doi:10.1016/j.cct.2008.09.006 